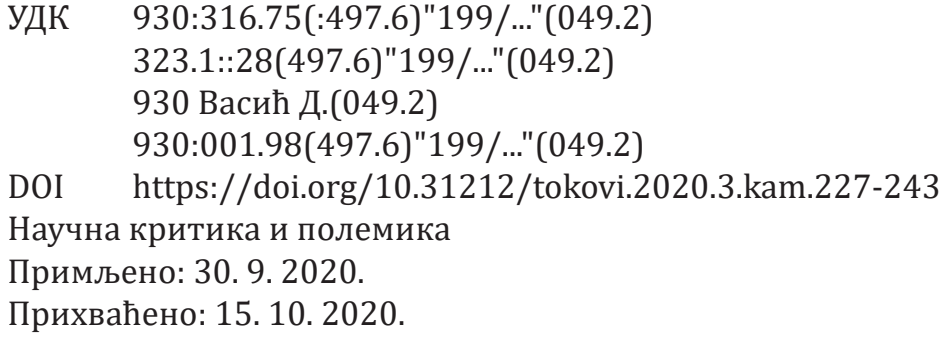

Научна критика и полемика

Примљено: 30. 9. 2020.

Прихваћено: 15. 10. 2020.

Husnija KAMBEROVIĆ

Filozofski fakultet, Univerzitet u Sarajevu

husnija.kamberovic@ff.unsa.ba

\title{
Sarajevska magla i teslićko-banjalučka „vedrina“: nenaučni stavovi u tekstu Dragiše D. Vasića o „bošnjačkom istorijskom narativu“
}

\begin{abstract}
APSTRAKT: U radu se osporavaju tvrdnje Dragiše D. Vasića u vezi sa stanjem historiografije u Sarajevu, te pokazuje koliko je Vasićev članak politikantski i bez naučnih kvaliteta. Na primjerima preimenovanja ulica u Sarajevu, „Bosanske doline piramida“, politike nastave historije u Sarajevu i festivala History Fest, autor pokazuje da Vasić ne donosi ništa novo, da ponavlja stare i poznate teze koje nemaju za cilj otvaranje naučnih diskusija nego sijanje mržnje. Autor tvrdi da se Vasić ne bavi ulogom historiografije u pojavama o kojima piše, nego prenosi stavove političkih elita, te je zbog toga Vasićev pristup historiografiji selektivan, nacionalistički obojen, sadrži politička etiketiranja i u skladu sa time posve je nenaučan.

KLJUČNE RIJEČI: historiografija u Bosni i Hercegovini, politizacije historije, nacionalizam
\end{abstract}

Dok se sarajevski historičari guše u magli, teslićko-banjalučki, u plavetnilu svoje nacionalne oaze, žive „kao bubreg u loju“. Tako bi se moglo zaključiti iz rada Dragiše D. Vasića ${ }^{1}$ „Istorija i nacionalni identitet u sarajevskoj magli: primjeri politizacije i mitologizacije bošnjačkog istorijskog narativa" objavljenog u časopisu Tokovi istorije. ${ }^{2}$ Ipak, kada se taj

1 Dragiša D. Vasić je, sudeći po biografiju distupnoj na službenoj stranici Filozofskog fakulteta Univerziteta u Banjoj Luci, rođen u Tesliću, a živi i radi u Banjoj Luci.

2 Драгиша Д. Васић, „Историја и национални идентитет у сарајевској магли: примјери политизације и митологизације бошњачког историјског наратива“, 
rad malo pretrese, jasno se vidi da nam ovdje Dragiša D. Vasić ne nudi ništa novo. Uhvatio se velike teme (politizacija i mitologizacija historije) i to propituje na primjeru „bošnjačke istoriografije i cjelokupnog bošnjačkog istorijskog narativa“. Da bi pokazao koliko su „bošnjačka istoriografija i cjelokupni bošnjački istorijski narativ" iz sarajevske kotline ispolitizirani i mitologizirani, Vasić navodi primjere promjene naziva ulica u Sarajevu, slučaj „Bosanske doline piramida“, neke primjere viktimizacije sadržane u udžbenicima historije u Kantonu Sarajevu, te primjer festivala historije History Fest. Sve su ovo dobra i velika pitanja, ali je u Vasićevom slučaju, po mom mišljenju, problematično i njegovo krivo razumijevanje pojmova, ali i to što on u ovom članku nije ponudio apsolutno ništa novo, a u dijelu u kojem želi nešto argumentirati on se zapliće u politizaciji i mitologizaciji historije, o kojoj, navodno, želi objektivno pisati.

Ali, krenimo redom.

Vasić na početku svoga rada tvrdi da će dokazati kako je „bošnjačka istoriografija", koju on smješta u sarajevsku maglu, ispolitizirana i mitologizirana, te da joj je cilj oblikovanje i učvršćivanje bošnjačkog nacionalnog identiteta. Čovjek bi se mogao ponadati da će Vasić ponuditi nešto novo, pogotovo što u uvodu nagovještava da će rad smjestiti u određeni teorijski okvir, pa se činilo da on može ponuditi neke nove perspektive. Lično sam se obradovao tome, jer sam se prije desetak godina bavio tom temom, a i prije godinu dana sam o tome objavio jedan rad. Prije desetak godina sam, naime, istraživao kakvu je ulogu imala historiografija u opravdavanju muslimanskog nacionalnog identiteta tokom 60 -ih godina, te kakvu je ulogu imala tokom 90-ih prilikom transformacije tog identiteta. Tada sam pokazao da je historiografija u Bosni i Hercegovini tokom 60-ih godina, kada se razvijala pod velikim političkim uticajem, bila jako angažirana u dokazivanju historijske utemeljenosti muslimanskog nacionalnog identiteta. Ponudio sam konkretne argumente (koji su naučni projekti i skupovi organzirani s tim ciljem, koji su historičari na tome radili i slično). ${ }^{3}$ Prije toga, Enver Redžić je dokazivao ulogu Muhameda Hadžijahića, kao ključnog promotora muslimanskog nacionalnog identiteta sredinom 60-ih, kao i ulogu Atifa Purivatre, Mustafe Imamovića i drugih. ${ }^{4}$ Sada se

Токови историје 2/2020, 209-232.

3 Husnija Kamberović, Historiografija u Bosni i Hercegovini u službi politike, (Zagreb: Srednja Europa, 2012), 19-32.

4 Enver Redžić, Stotinu godina muslimanske politike u tezama i kontroverzama istorijske nauke. Geneza ideje bosanske, bošnjačke nacije, (Sarajevo: Akademija nauka i umjetnosti i Institut za istoriju, 2000), 89-100. 0 tome treba vidjeti i knjigu: Xavier Bougarel, Nadživjeti carstva: islam, nacionalni identitet i politička lojalnost u Bosni 
tog posla dohvatio i Dragiša D. Vasić! Ali - on ne nudi nikakve nove naučne argumente i ne otvara nikakve nove perspektive. Selektivan je, ne koristi literaturu koja o tome konkretno govori (čak iako neke od tih knjiga navodi u fusnotama to ostaje samo na razini navođenja bibliografske natuknice), njegovo pisanje je puno političkih etiketiranja, ne donosi nikakve naučne argumente, što, priznajem, otežava bilo kakvu naučnu raspravu.

Ali, ipak, pokušajmo naći neki sistem i detektirati glavne tačke o kojima bi se moglo nešto koliko-toliko suvislo kazati.

Krenimo od analize pojmova koje Vasić koristi. Ja ću se zadržati samo na pojmu „bošnjačka istoriografija“, što možda i nije tako važno u ovom njegovom radu, ali je to pitanje dobro polazište da možemo razumjeti cjelinu Vasićeve poruke. Ovdje se on ponaša kao da otkriva toplu vodu, a ustvari ponavlja stvari o kojima se već raspravljalo. Kada bi makar i malim dijelom dodavao nešto novo u tu staru diskusiju, to bi još i moglo da izazove neku novu raspravu. Ali, ne! Vasić samo ponavlja od ranije poznate stvari, pa je njegov članak, zapravo, samo dobar primjer politizacije i mitologizacije historije kao nauke.

Da bi pokazao kako je „bošnjačka istoriografija“ politizirana i mitologizirana, Vasić polazi od aksioma da postoje tri dominantne interpretacije historije Bosne i Hercegovine: bošnjačka, srpska i hrvatska. Nije prvi, niti jedini, niti posljednji, koji tako definira stanje historiografije u Bosni i Hercegovini. To je raširen narativ i na njemu posebno insistiraju nacionalisti u Bosni i Hercegovini, a stranci (ne svi) to vrlo često, i olako, prihvataju. 0 tome sam i sâm prije nekoliko godina pisao, kada sam vodio neke druge polemike. I tada sam postavljao pitanje: Šta je to „bošnjačka historiografija"? Po mom mišljenju, što ne znači da se drugi s tim moraju saglasiti, u Bosni i Hercegovini ne postoji ni bošnjačka ni srpska ni hrvatska ni bosanskohercegovačka historiografija, ali postoje brojni historičari (sada bismo mogli reći i historiografski centri - Sarajevo, Tuzla, Mostar, Banja Luka) koji na različite načine interpretiraju povijest Bosne i Hercegovine, a bave se i znatno širim temama. ${ }^{5}$ Neki su parahistoričari i samo politiziraju i mitologiziraju historiju, a neki se bave prošlošću kao pravi naučnici. Granica nije definirana nikakvim nacionalnim kriterijem. To što je neko Bošnjak, Srbin ili Hrvat ne znači da samim tim pripada „bošnjačkoj“, „srpskoj“ ili „hrvatskoj“ historiografiji. Konkretno: ne postoji nikakav koncept (metodološki, tematski ili slično) „bošnjačke historiografije“, a to

i Hercegovini, (prijevod sa francuskog), (Sarajevo: Udruženje za modernu historiju, 2020).

5 Kamberović, Historiografija u Bosni i Hercegovini, 91. 
što pojedini historičari koji su Bošnjaci politiziraju i mitologiziraju povijest - ne znači da je to bošnjačka historiografija. Gdje pripadaju oni historičari koji jesu Bošnjaci i koji ne politiziraju prošlost? Nije, valjda, bošnjačka historiografija samo ono što pišu (ili su pisali) Enver Imamović ili Mustafa Imamović (jer su Bošnjaci i jer su pisali u funkciji afirmacije Muslimana/Bošnjaka kao nacije), a nije bošnjačka historiografija ono što pišu (ili su pisali) Dževad Jubašić i Ever Redžić, koji u svemu kritiziraju ono što su pisala oba Imamovića. Gdje li pripada jedan Ahmed S. Aličić, koji je pisao najoštrije kritike na Historiju Bošnjaka Mustafe Imamovića, ali je hvalio sve što je pisao Ibrahim Pašić, koji je, opet, napadao sve što su pisali Enver Imamović i Mustafa Imamović? Gdje pripadaju historičari koji jesu Srbi ali na povijest ne gledaju na način kako to gleda Dragiša D. Vasić? Mogli bismo postavljati niz ovakvih pitanja. Po mom mišljenju, Vasić je krenuo od tog (krivog) „aksioma“ postojanja nacionalnih historiografija u Bosni i Hercegovini kako bi mogao razvijati dalju priču u svom radu i kako bi „bošnjačku istoriografiju“ smjestio na mitološku stranu. Sigurno je da mnogi i u Bosni i Hercegovini žele konstruirati isključivo tri nacionalne historiografije, sve smjestiti u nacionalne torove, ali to više nije historiografija nego politizacija historiografije. A to ovim svojim radom upravo želi i Dragiša D. Vasić. Uostalom, među historičarima u Bosni i Hercegovini ima nas koji historijsku nauku ne dijelimo na srpsku, hrvatsku ili bošnjačku, iako istražujemo i teme iz nacionalne historije. Iz popisa literature na kraju njegovog članka vidljivo je da je i Vasić čitao te radove, ali oni nisu ostavili nekog traga na njegovo razumijevanje historije. No, nije to do njega, nego do onih koji su o tome pisali. Ipak, da je Vasić čitao radove iz zbornika Historijski mitovi na Balkanu, mogao je vidjeti da smo i tu na konkretnim primjerima kritizirali politizaciju i mitologizaciju historije ne samo u Bosni i Hercegovini nego i drugdje. ${ }^{6}$ I tada smo pošli sa stanovišta da nije sve što se napiše o prošlosti historijska nauka. Nešto pripada parahistoriji. Ovaj rad Dragiše D. Vasića, u kojem se na početku konstruirana „bošnjačka istoriografija“ optužuje da „potencira neprijateljstvo prema susjedima, posebno prema Srbima", nije ništa drugo do političko etiketiranje. Taj rad, zapravo, potencira mržnju. Mržnju prema historijskoj nauci.

U nastavku svoga rada Vasić raspravlja o polemikama u vezi s nazivima ulica u Sarajevu. Pri tome malo govori o historiografiji a puno više o politici. Opet samo ponavlja poznate stvari, ali ih pokušava predstaviti kao nove. Upravo na tom primjeru se vidi koliko je neodrživo njegovo

$6 \quad$ Historijski mitovi na Balkanu, zbornik radova, ur. Husnija Kamberović, (Sarajevo: Institut za istoriju, 2003). 
insistiranje o „bošnjačkoj historiografiji“. Tarik Haverić je pokrenuo pitanje Busuladžića, ${ }^{7}$ Nenad Veličković je o tome pisao puno, ${ }^{8}$ Tomislav Išek je o tome javno govorio, a pisali su i govorili mnogi drugi. I ja sam bio jedan od onih koji su pisali kako je politika iskoristila Institut za historiju u Sarajevu da bi dobila „potvrdu“ da je Mustafa Busuladžić bio „jedan od vodećih muslimanskih intelektualaca" i da je, navodno, ubijen samo zato što je bio antikomunista, i tako dalje. Mediji u Sarajevu su o tome opširno izvještavali. Vasić, doduše, neke od tih naših istupa navodi u svojim fusnotama, ali je moje pitanje: koja je svrha tog dijela članka, jer se u njemu ne donosi apsolutno ništa novoga? Želi se pokazati kako se u Sarajevskoj kotlini mijenjaju nazivi ulica, uklanja „Đedo, a dodaje Dedo“ i time pokazati politizaciju historije? Ali, ne odgovara na pitanje kakav je o tome stav akademske zajednice u Sarajevu. Mogao je to Vasić lako utvrditi. ${ }^{9}$ Tačno je da je Institut za historiju podržao imenovanje škole u Dobroševićima (ne Dobraševićima, kako piše Vasić) po Mustafi Busuladžiću, ali smo i ja i mnogi drugi to osudili, o tome pisali i u javnosti se tome suprotstavili. ${ }^{10}$ Nije nam trebao Dragiša D. Vasić da sada sve to što smo mi pisali - ponovi kao neko svoje veliko otkriće i plasira u časopisu Tokovi istorije. Ali, on kao argument uzima samo dio političke i akademske javnosti koji njemu ide u prilog, i iz toga izvlači „dalekosežne“ zaključke. Jer, da je kao naučnik bio korektan i uzeo u obzir cjelinu rasprava u vezi s nazivima ulica ili u ovom konketnom slučaju u vezi s nazivom jedne škole, postalo bi mu sasvim jasno da je u Sarajevu većina naučnika bila protiv toga. ${ }^{11}$ Kao što je i

$7 \quad$ Tarik Haverić, Kritika bosanskog uma. Ogled o jednom historijski fiksiranom mentalitetu, (Sarajevo: ECLD, 2016), 74-85, 269-310. Haverić ne raspravlja samo o Mustafi Busuladžiću. Njegova knjiga je znatno šira, nije historijska rasprava, ali nudi analizu stanja u kojem se kreiraju slike prošlosti.

8 Nenad Veličković, Akademsko šarlatanstvo. Nauka o književnosti i univerzitet u tranziciji - etnografski pristup. (Sarajevo - Beograd: Edicija Reč, 2019), 151-159.

9 Husnija Kamberović, „Slučaj Mustafe Busuladžića - sa povijesne margine ka politikantskom centru“, Na margini povijesti, zbronik radova, (Sarajevo: Udruženje za modernu historiju, 2018), 121-134.

10 Nenad Veličković je u svojoj knjizi, pišući o tome, jedno poglavlje naslovio „Institut za histeriju“.

11 Zanimljivo bi bilo i da se Vasić potrudio saznati kako su se uopće mijenjali nazivi ulica u pojedinim gradovima u Bosni i Hercegovini. Prema nekim istraživanjima provedenim prije 15-ak godina, u Sarajevu je u odnosu na 1992. nazive promijenilo 59,6\% ulica, u Banjoj Luci 46,4\% i tako dalje (vidjeti: Heiner Grunert, „Raum, Zeit und deren Namen. Geschichte der Namen von Straßen und Plätzen in Sarajevo“, (rukopis), s. a., s. l.; Srđan Šušnica, „Pop-mitološko označevanje 'naših' ulic. Študija primera Banje Luke, Bosna in Hercegovina“, (magistarsko delo, Ljubljana, 2015). No, ovdje je ključno pitanje uloge historičara u tom procesu mijenjanja naziva ulica, o čemu Vasić izbjegava pisati, iako na početku rada obećava da će se baviti historiografijom. 
protiv imenovanja studentskog doma na Palama po Radovanu Karadžiću. Ali, tada bi Vasićeva teza ostala bez argumenata.

Uostalom, da je htio biti korektan, Vasić je mogao navesti da sam ja bio najoštriji kritičar stavljanja Instituta za historiju u Sarajevu u funkciju politike. Evo šta sam o tome napisao: „Dok su etnički poduzetnici među historičarima iz Banje Luke, uplašeni za svoje nacionalno biće, svaki naučni dijalog pokušavali svesti na dijalog nacija, njihovi idejni partneri iz Sarajeva su počeli izravno služiti bošnjačkoj vladajućoj političkoj garnituri. Relativno brzo stavljanje Instituta za historiju, kao vodeće naučne institucije iz oblasti historijskih istraživanja u Bosni i Hercegovini, pod politički uticaj, ovdje ću pokazat na dva primjera: jasnom podrškom za neku vrstu rehabilitacije Mustafe Busuladžića, koga su komunisti 1945. osudili na smrt i strijeljali, te podršci nastojanju gradonačelnika Sarajeva da se utvrdi Dan osnivanja Sarajeva.

Prvi primjer je pokazao da se Institut za historiju ne samo aktivno uključio u obračun sa komunističkim naslijeđem, nego i u kreiranje posve novih narativa u skladu sa vladajućom ideologijom. (...) U 'slučaju Busuladžić', jedna ozbiljna naučna institucija, a Institut za historiju je to bio, uvučena je u političku arenu, iskorištena u jednokratnu političku upotrebu, a ubrzo su oni koji su u tome sudjelovali, odbačeni od iste te političke skupine koja je 'naš' Institut od relevatne naučne ustanove pretvorila u instituciju za pokriće već donesenih političkih odluka. Radovi Tarika Haverića i Nenada Veličkovića, koji je s pravom ustvrdio da je Institut za historiju ovom podrškom u građenju posve novog narativa o Mustafi Busuladžiću postao 'Institut za histeriju', ostat će kao vrijedno svjedočanstvo o transformaciji jedne naučne institucije, kakva je postojala 2013. godine, u običnu politikantsku ustanovu. ${ }^{12}$

$\mathrm{Na}$ istom mjestu Vasić je mogao vidjeti, a potom i to uzeti u obzir u svojoj analizi, koliko sam energije uložio osporavajući političku inicijativu za utemeljenje datuma osnivanja grada Sarajeva. Uprkos stavu Instituta za historiju, naše protivljenje je dalo rezultate. Ali, ne! To ne odgovara Vasiću. Njemu nikako ne ide u prilog sagledavanje pitanja u cjelini. Parcijalni pristup jedino mu ostavlja prostor za kvazinaučne konstrukcije.

Isti je slučaj i sa „Bosanskom dolinom piramida“. Opet Vasić otkriva toplu vodu ne nudeći ništa novo, budući da sve to što sada kritizira mi smo već kritizirali! Nijedan ozbiljan historičar nije podržao taj Osma-

12 Husnija Kamberović, „Historičari kao nacionalni radnici i politizacija historiografske scene u Bosni i Hercegovini“, Ogledi o historiografiji i nacionalizmu u jugoistočnoj Evropi, zbornik radova, (Sarajevo: Udruženje za modernu historiju, 2019), 162-163. 
nagićev projekt, ali vlasti jesu. Ovdje dolazi u pitanje i to zna li Vasić da historiografija nije sve šte se napiše o nekoj temi „iz ljudske i geografske prošlosti“. Čak štaviše: mnogi u Sarajevu su protiv toga pisali. Lično sam o tome pisao već 2006 . godine. ${ }^{13}$ Priznaje to čak i Vasić, ali ipak istrajava u svoj priči o „piramidama“ kako bi pokazao kako u Sarajevu „prodaju maglu“ sa „Bosanskom dolinom piramida“. Dakle, u Sarajevu se ne može naći nijedan ozbiljan naučnik, a nijedan historičar koji je podržavao tu ideju. Vasić kao argument navodi izjave Semira Osmanagića (čije djelovanje i sam kvalificira „šarlatanstvom“) o „piramidama“, pa čak navodi i njegove izjave da ga ne zanima priznanje akademske zajednice, nego insistira na „alternativnoj historiji“ $\mathrm{i}$ „alternativnoj istini“. Uprkos svemu tome, Vasić istrajava na tome da je Osmanagić „sarajevsko akademsko čedo“, što za njega očito ima neko posebno značenje. Međutim, ima nas, koji živimo i radimo u Sarajevu, koji ne podržavamo Osmanagića, nismo „sarajevsko akademsko čedo", iako nas Vasić pokušava ugurati u nacionalni tor. Mimo naše volje! Ja želim samo ostati profesionalni historičar, a ne graditelj nacionalnog identiteta. Tu ulogu rado prepuštam Vasiću. Mada bi i za njega kao naučnika bilo puno bolje da na prošlost prestane gledati samo iz nacionalne perspektive. Ali, to je već neka druga priča!

Naredno pitanje o kojem Vasić piše tiče se viktimološkog narativa u udžbenicima historije i genocida nad Bošnjacima. I tu pokušava pojednostaviti stvari. Njegova analiza se zasniva na parcijalnim izvorima. Može se svašta naći u ovom dijelu Vasićevog članka, ali dobro je da se razlikujemo u razumijevanju i interpretacijama historijskih događanja (on ponavlja tezu o tome da Sarajevo nije bilo „pod opsadom“ nego „podijeljeni grad“ 1992-1995; ${ }^{14}$ da se u Srebrenici desio „masovni zločin“, a ne „zločin genocida“ iako je Međunarodni sud u Hagu precizno okarakterizirao šta se desilo u Srebrenici i kakav status Sarajeva je bio tokom rata 1992-1995. godine). ${ }^{15} \mathrm{O}$ svemu tome se raspravljalo i prije Vasića, ali ovdje je zanimljivo

13 Kamberović, Historiografija u Bosni i Hercegovini, 71-72.

14 Podjela Sarajeva je bila jedan od šest strateških ciljeva usvojenih na Skupštini Republike Srpske u maju 1992. Inače, nakon što su usvojeni Strateški ciljevi, čak je i Ratko Mladić izjavio da je to nemoguće realizirati bez provođenja genocida (,ja ne znam kako će gospodin Krajišnik i gospodin Karadžić objasniti svijetu. To je ljudi genocid“, izjavio je Mladić). Vidjeti: Robert J. Donia, Iz Skupštine Republike Srpske. Izvodi iz izlaganja poslanika Skupštine Republike Srpske kao dokazni materijal na Međunarodnom krivičnom tribunalu u Hagu, (Sarajevo: University Press, 2012).

15 Bilo je eksperata koji su i na Sudu u Hagu pokušavali opsadu Sarajeva i genocid u Srebrenici karakterizirati na način kako to radi i Vasić, ali su ti pokušaji završili dosta neuspješno. Vidjeti, na primjer: Miloš Ković, Draga Mastilović, Pravo na istoriju. Svedočenje u procesu Haškog tribunala protiv generala Ratka Mladića, (Beograd: Cate- 
opet napomenuti da on pojednostavljuje pojave i parcijalno koristi informacije, čak i posve krivo. Tako, na primjer, dolazi do mog odnosa prema Mustafi Imamoviću i o tome kako ja imam razumijevanja za Imamovićeve tvrdnje, te piše da ja Imamovića smatram „doajenom muslimanske/bošnjačke istoriografije" i žalim što nije primljen u Akademiju nauka i umjetnosti Bosne i Hercegovine. Ja sam, međutim, pisao da je Imamović imao „jako izraženi smisao za sintezu. Prije njega takav dar je u historiografiji u Bosni i Hercegovini možda imao jedino Muhamed Hadžijahić“. Ne svrstavam Imamovića u „doajene bošnjačke histriografije“, nego ga promatram u kontekstu „historiografije u Bosni i Hercegovini“. Iz ove perspektive bih i Milorada Ekmečića uvrstio među historičare iz Bosne i Hercegovine sa jako izraženim smislom za velike historijske sinteze.

Kada već citira Imamovićev intervju listu Dani o tome šta misli o svojoj Historiji Bošnjaka, za Vasića bi bilo dobro da je doista tu izjavu uzeo i analizirao u cjelini, a ne samo djelimično, kao što su to učinili i mnogi prije njega. Na taj Imamovićev intervju već su reagirali i neki drugi naučnici, a njihove kritike sam objavio u zborniku Historijsku mitovi na Balka$n u^{16}$ (što Vasić izbjegava čak i spomenuti). Koliko je površan (da li samo površan?) pokazuje i to da je Imamovićevu izjavu interpretirao tako kao da ona glasi da je njegova Historija Bošnjaka „mitologija“. Zanimljivo! Ovo je dobar primjer stare tvrdnje kako jedan piše, a ostali prepisuju.

Kada su u pitanju nastava historije u školama i udžbenici, valja naglasiti da sam saglasan da su programi i udžbenici za nastavu historije u Bosni i Hercegovini, kao i u ostalim postjugoslavenskim zemljama, loši, ne samo u Sarajevu. Nažalost, školski sistem u Bosni i Hercegovini je razbijen, nastavni programi su etnicizirani, pod velikim su uticajem susjednih zemalja, udžbenici su često ispolitizirani. Razna udruženja koja se time bave, po mom mišljenju, uprkos određenim naporima, nisu daleko odmakla. Zašto je to tako - drugo je pitanje kojim se ovdje ne mogu baviti.

Posljednji dio Vasićevog članka se tiče izravno mene i History Festa. Vasić, nažalost, samo iznosi političke kvalifikacije, a nikakve naučne argumente. I - opet ponavlja sve što je poznato. Na pismo Studijskog programa Istorija Filozofskog fakulteta Univerziteta u Banjoj Luci već sam ranije odgovorio, ${ }^{17}$ pa se sada pitam da li je potrebno na ovom mjestu to ponavljati? Naime, sve što sada Vasić problematizira sadržano je u tom pi-

na mundi, 2018). Uporediti: Robert J. Donia, Sarajevo. A Biography, (London: Hurst\&Company, 2006).

16 Historijski mitovi na Balkanu, 48-49, 85 i dalje.

17 Kamberović, „Historičari kao nacionalni radnici“, 149-170. 
smu, a sve što bih sada odgovorio - sadržano je u mom odgovoru na to pismo! No, budući da je Redakcija časopisa Tokovi istorije objavila ovaj Vasićev članak, prisiljen sam i sâm ponoviti ono što sam ranije o tome pisao.

Dakle, jednu od manifestacija u okviru History Festa 2019. trebali smo održati u Banjoj Luci. U planu su bili okrugli sto o revizionizmu u historiografiji i promocija knjige Ive Goldsteina o Jasenovcu. U pripremi tog događaja iz Banje Luke sam pozvao Vladana Vukliša da sudjeluje u okruglom stolu, jer se bavio pitanjima o kojima smo trebali raspravljati. Čak je napisao i jednu odličnu recenziju knjige Bosna i Hercegovina u drugom svjetskom ratu, a prethodnih godina je bio učesnik na History Festu u Sarajevu i imali smo dobru saradnju. Prije moje ponude da sudjeluje u ovom banjalučkom događanju, Vukliš je predlagao da organizira jedan poseban panel u okviru History Festa u Sarajevu, na koji bi pozvao svoje kolege iz inozemstva s kojima inače sarađuje na nekim drugim projektima. Ali, kada sam mu predložio da učestvuje u radu okruglog stola u Banjoj Luci - odustao je od učešća u History Festu, pravdajući to obavezama na doktorskom studiju i potrebi završetka disertacije. Ako ništa onda je to zanimljivo.

Okrugli sto o revizionizmu moderirao je Milivoj Bešlin iz Novog Sada. Učesnici su bili po jedan historičar iz svih postjugoslavenskih zemalja. Nakon što je Vukliš odustao - ja sam „uskočio“ iz Bosne i Hercegovine. Sada Vasić, a to su i ranije učinili u Pismu Studijskog programa Istorija, baca drvlje i kamenje na Milivoja Bešlina kao moderatora, te insinuira da organzatoru smeta naziv Narodnog pozorišta Republike Srpske i pozorišne scene „Petar Kočić“. Objasnimo malo obje primjedbe.

Prvo, u vezi s Milivojem Bešlinom: on je bio moderator panela, a čak ni Vasić sada, kao što nisu ni u pismu Studijskog programa Istorija iz 2019, ne osporava Bešlinove naučne kompetencije, nego iznosi političke diskvalifikacije. To nema nikakve veze niti sa naukom niti sa History Festom. To je, zapravo, čista politizacija, protiv čega se, navodno, Vasić bori.

Drugo je pitanje naziva Narodnog pozorišta u Banjoj Luci. Tačno je da je u programu to navedeno samo kao „Narodno pozorište“. Ali ne zbog toga što to nekome smeta! Naime, dugo je bilo neizvjesno gdje ćemo dobiti prostor za održavanje History Festa u Banjoj Luci. Prvobitno smo željeli u jednom hotelu, pa nije bilo mjesta, a potom smo dobili informaciju da to možemo napraviti u „Narodnom pozorištu“ (na temelju čega sam ja dao da se štampa program), da bi na kraju dobili fantastičnu ponudu: da to bude na Maloj sceni Narodnog pozorišta Republike Srpske, kako sam dao da se štapa na plakatu u kojem najavljujemo promociju knjige Ive Gold- 


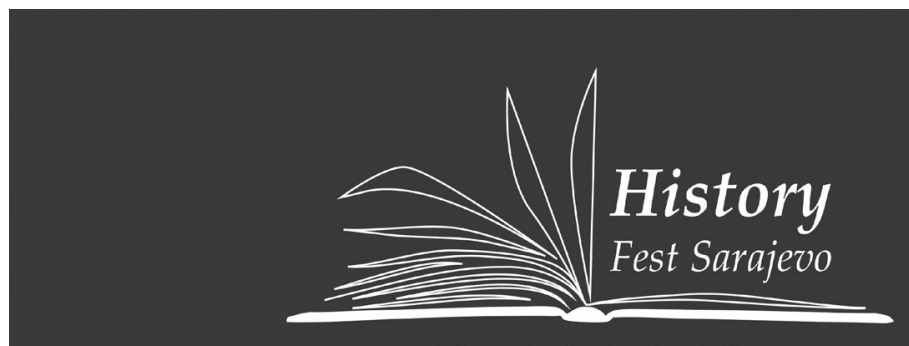

28. maj-2. juni 2019.

Pozivamo Vas na predstavljanje knjige JASENOVAC

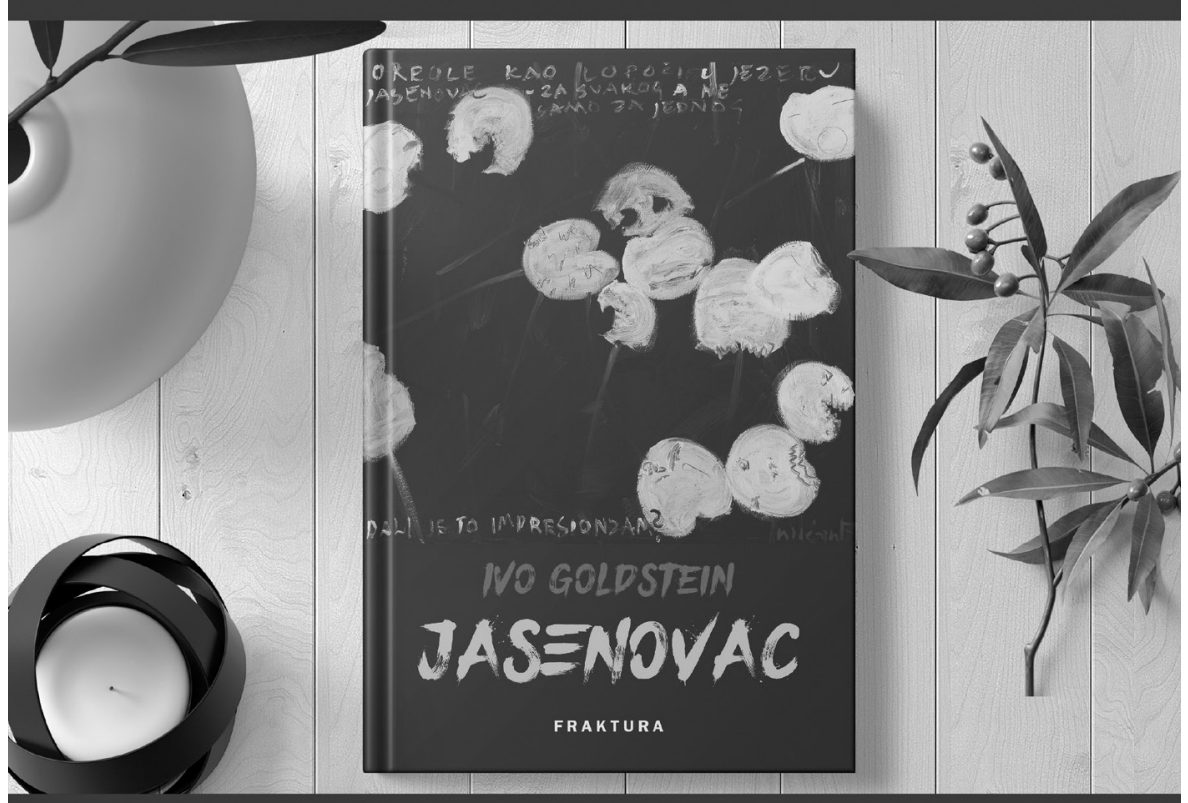

Učestvuju: Ivo Goldstein, Goran Hutinec i Seid Serdarević

Petak • 31. maja 2019. • u 17:00 sati • Narodno pozorište Republike Srpske • Mala scena • Banja Luka • Kralja Petra I Karađorđevića br. 78

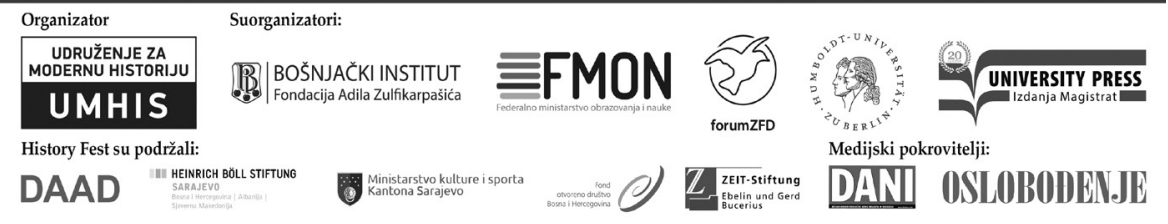


steina o Jasenovcu, što se može vidjeti i iz priloženog plakata. Lično sam bio sretan zbog tog prostora, pogotovo što smo scenu pozorišta trebali dobiti besplatno. 0 tome sam mnogima u Sarajevu i izvan Sarajeva pričao i hvalio se kako smo od Uprave Narodnog pozorišta u Banjoj Luci dobili besplatno prostor, dok su nam u Sarajevu tražili nekoliko hiljada maraka samo za otvaranje Festa u Vijećnici (što sam, naravno, sa gađenjem odbacio). Nažalost, to jutro, dok smo bili u autobusu na putu za Banju Luku, dobio sam SMS poruku da je „pukla cijev“ u pozorištu i da Uprava otkazuje gostoprimstvo. Naravno da nisam želio odustati od razgovora i promocije, pa smo sve na brzinu organizirali u jednom drugom hotelu, gdje smo inače bili smješteni, ali u prostoru koji nije adekvatan niti značaju okruglog stola niti značaju knjige Jasenovac. Dakle, nije riječ o tome da li se meni ili nekome drugom ne dopada naziv Narodnog pozorišta. Ne znam kako to Vasić zna šta se meni dopada, a šta ne dopada? Možda ima neke posebne, nadnaravne moći? Osim toga, u Banjoj Luci smo planirali dva događaja, jedan za drugim, a u Sarajevu smo imali nekoliko paralelnih događaja, pa je bilo sasvim normalno navesti tačne nazive sala u Bošnjačkom institutu kako bi učesnici panela, ljetne škole i doktorske radionice mogli tačno znati u kojem prostoru se održava koji događaj.

Posljednje pitanje, koje i Vasić ovdje postavlja, a sadržano je i u Pismu Studijskog programa Istorija, odnosi se na slabo učešće istoričara iz Repubike Srpske, sastav istoričara iz Republike Srbije, te selekciju političkih aktivista s početka 90-ih koji su sudjelovali u panelu o raspadu Jugoslavije. Vasić mi prigovara da sam pozvao Raifa Dizdarevića, Milana Kučana i Stjepana Mesića, a da nije bilo relevatnih srpskih i crnogorskih političara. Iako sam i ovo objasnio u mom ranijem odgovoru, moram sada ponoviti: u History Festu ne sudjeluju predstavnici nekih nacionalnih historiografija (sada je jasno zbog čega Vasić toliko insistira sa srpskoj, hrvatskoj i bošnjačkoj historiografiji u Bosni i Hercegovini) niti bilo kakve nacionalne reprezentacije, nego historičari koji se bave određenim temama i koji su afirmirani u svojoj struci. Tako su, na primjer, na History Festu 2017. iz Banje Luke sudjelovali Boro Bronza, Vladan Vukliš, Boško Branković i Borivoje Milošević, koji su predstavili svoj projekt Istorija jugoslovenske ideje, ${ }^{18}$ a potom i izdanja Filozofskog fakulteta Univerziteta u Banjoj Luci; godine 2018. na History Festu su sudjelovali iz Banje Luke Boro Bronza i Vladan Vukliš. Ali, oni nisu bili tu kao članovi neke „srpske reprezentaci-

18 Kada je objavljena knjiga kao rezultat tog projekta, u Sarajevu sam, kao predsjednik Udruženja za modernu historiju, organizirao promociju koja je održana u prostorijama Nacionalne i univerzitetske biblioteke. 
je“, nego kao historičari koji se bave određenim temama o kojima se raspravlja na History Festu, jer on nije nikakav politički skup, nego naučna manifestacija. Bit će mi drago da u Banjoj Luci izraste generacija historičara koja će moći, željeti i imati hrabrosti sudjelovati u ovakvim naučnim diskusijama. Kao profesionalni historičari. A ne kao profesionalni Srbi. A oni koji žele politizirati historiju - želim im sve najbolje. Samo, bez mene! I - izvan History Festa.

A što se tiče historičara iz Republike Srbije, doista mi je jako drago da u History Festu sudjeluju historičari poput Latinke Perović, Dubravke Stojanović, Nikole Samardžića, Radine Vučetić, Milivoja Bešlina i brojnih drugih. Njima su otvorena vrata svih svjetskih univerziteta, i lično mi je drago da nađu vremena doći i na History Fest. Ali, svi su oni ovdje zato što su dobri i profesionalni historičari. Jednako kao što su tu i brojni historičari iz Hrvatske, Makedonije, Crne Gore, Slovenije, Austrije, Njemačke, Francuske, SAD-a, Rusije, Turske i drugih zemalja. Ipak, ostaje nejasno u Vasićevom pisanju zašto su sporni Latinka Perović, Dubravka Stojanović i drugi? Možda zato što nisu u nacionalističkoj kotlini ili zato što su u vrhu svjetske historiografije?

Posljednje pitanje u vezi s History Festom 2019. koje je pokrenuto i u Pismu Studijskog programa Istorija, a i sada u ovom Vasićevom radu (stalno ponavlja stare i poznate stvari!) odnosi se na primjedbu kako sam selektivno pozvao političare, te da nedostaju relevantni srpski i crnogorski političari svjedoci raspada Jugoslavije. Istina je da sam na panel o raspadu Jugoslavije zvao članove posljednjeg Predsjedništva SFRJ, koji su još uvijek živi (Stipe Mesić, Bogić Bogićević, Borisav Jović, Vasil Tupurkovski i Branko Kostić). Milan Kučan je bio gost History Festa zbog promocije knjige koju je o njegovom životu napisao slovenački povjesničar Božo Repe. Bila je prisutna i Ljubinka Trgovčević, koja je bila član Predsjedništva SR Srbije prije rata. Članovi Predsjedništva SFRJ su trebali imati razgovor u Konjicu, u Titovom Bunkeru, kako se obično naziva taj objekat D-0. Ali, stvari su se odvijale u tom pravcu da ni Bogić Bogićević ni Vasil Tupurkovski, obojica iz zdravstvenih razloga, nisu mogli doći, iako su do posljednjeg trenutka imali namjeru. Zato su u Bunkeru razgovarali Mesić, Kučan i Dizdarević, iako su u Programu History Festa kao panelisti bili najavljeni Stipe Mesić, Vasil Tupurkovski i Bogić Bogićević. Ali, zašto nema Jovića i Kostića?

Kostić je odgovorio da ne želi više nikako razgovarati o svojoj ulozi u vrijeme raspada Jugoslavije, jer je o tome već dovoljno kazao i napisao, ali je moju ideju o razgovoru sa ostalim članovima Predsjedništva podržao kao korisnu. Čak mi je poslao svoje dvije posljednje knjige o tome. 
Sa Borisavom Jovićem sam puno razgovarao, nekada telefonom, a nekada je ta komunikacija išla e-mailom. Uglavnom, on je odustao nakon što mu nisam organizirao susret sa Miloradom Dodikom, što je shvatio kao moju grešku. Ja sam, međutim, odbio politizirati History Fest, ali sam i o njegovom dolasku, kao i o dolasku Kučana, Mesića i drugih, obavijestio članove Predsjedništva Bosne i Hercegovine, uključujući i Milorada Dodika, odnosno njegov kabinet. Zašto sam obavijestio članove Predsjedništva? Upravo zbog Borisava Jovića, jer mi je bilo stalo da on bude jedan od učesnika, ali nisam bio siguran da li eventualno ima neka prijava protiv njega zbog uloge koju je imao u procesima 1990-1992. godine, koja bi njega, ali i mene kao organizatora, mogla dovesti u nezgodnu situaciju u slučaju dolaska u Sarajevo. Računao sam da to, svakako, moraju znati u Predsjedništvu i da bi mi na to ukazali, posebno iz kabineta Milorada Dodika, a i moja ponuda članovima Predsjedništva BiH da prime članove posljednjeg Predsjedništva SFRJ je bila u funkciji stvaranja ambijenta za bezbjedan boravak svih učesnika, a posebno gospodina Jovića. Borisav Jović je, međutim, insistirao da mu organiziram poseban prijem kod Milorada Dodika, što bi sigurno značilo politizaciju čitavog festivala. Međutim, ja sam želio da on bude učesnik History Festa a da slobodno vrijeme provede obilazeći sarajevske muzeje, galerije, planirao sam i da posjeti Srpsko kulturno društvo „Prosvjeta“ i drugo, ali bez ikakve politizacije. Nezadovoljan što mu nisam organzirao susret sa Dodikom - Jović je odustao od dolaska u Sarajevo. Tako se može zaključiti iz naše e-mail prepiske. A da li je još nešto uticalo na njega da odustane od dolaska u Sarajevo - to doista ne znam.

Ostaje mi, ipak, nejasno šta znači to što Vasić na kraju svoga članka samozadovoljno likuje kako sam „uhvaćen in flagranti“ u vezi s History Festom? Ali, ono u šta sam siguran jeste da će History Fest i dalje njegovati i promovirati otvoreni naučni dijalog, ali nikada neće postati platforma za širenje nacionalizma ili politizaciju historijske nauke. Politikanti mogu tražiti neke druge platforme i oblike djelovanja. Tu me Dragiša D. Vasić može uhvatiti in flagranti, kako on kaže.

U Vasićevom tekstu, nažalost, nema nikakvih naučnih tvrdnji i nikakvih naučnih argumenata, nego se sve svodi na politizaciju. On uopće ne analizira rasprave u History Festu, što bi, naravno, imalo smisla. Kada sam prošle godine pisao odgovor na Pismo Studijskog programa Istorija i kada sam naveo da su historičari koji iza toga stoje, zapravo, „nacionalni radnici“, nisam znao koja su to imena. Ni sada nisam siguran da je Va- 
sić predvodnik te grupe, ali jeste, valjda, jedan djelić. U pozadini je, ipak, neko drugi.

Da zaključim: Dragiša D. Vasić History Fest kvalificira „primitivnom antisrpskom političkom provokacijom". Takva kvalifikacija, rekli bismo njegovim rječnikom, doista je primitivna!

\section{Rezime}

U članku o „bošnjačkom istorijskom narativu“ Dragiša D. Vasić tvrdi kako je savremena bošnjačka historiografija ispolitizirana, i to argumentira navodeći četiti primjera: promjene naziva ulica u Sarajevu, odnos prema „Bosanskoj dolini piramida“, pojedini primjeri viktimizacije sadržani u udžbenicima historije u Kantonu Sarajevo, te festival historije History Fest. Vasićeva polazna pozicija je kriva, jer bošnjačka historiografija, kao metodološki i tematski koncept, ne postoji, a znatan dio naučnika u Sarajevu, neovisno o svojoj nacionalnoj pripadnosti, nije podržavao upotrebu historiografije u političke svrhe i kritizirao je odnos političke elite prema nazivima nekih ulica i škola u Sarajevu, posebno škole u Dobroševićima nazvane po Mustafi Busuladžiću. Također, značajan dio akademske zajednice u Bosni i Hercegovini i Sarajevu nije podržao ni ideju o „Bosanskoj dolini piramida“, pa su neutemeljene Vasićeve tvrdnje da je to „bošnjački istorijski narativ“.

Udžbenici historije, ne samo u Sarajevu, nisu najbolji, ali je Vasićev pristup toj analizi selektivan, površan, etnocentričan i nenaučan. Njegove ocjene o tome da Sarajevo nije bilo „opkoljeno“ tokom rata 1992-1995. nego „podijeljeno", te da se u Srebrenici nije desio genocid nego „masovni zločin“ pokazuju da je njegov pristup historiografiji politikantski. Iako u udžbenicima koji su u upotrebi u Kantonu Sarajevo ima mitologizacije, tvrdnje da je Sarajevo 1992-1995. bilo opkoljeno, te da se u Srebrenici 1995. desio zločin genocida su činjenice koje je utvrdio Međunarodni sud u Hagu.

History Fest 2019, o kojem Vasić piše tvrdeći da je to „politička provokacija", jeste manifestacija koja okuplja historičare iz čitavog svijeta, nije politički motiviran i održava se u raznim gradovima Bosne i Hercegovine s ciljem širenja naučnog dijaloga uz čuvanje visokih naučnih kriterija. Učesnici ne predstavljaju nikakve „nacionalne reprezentacije“, pa je odustajanje historičara iz Banje Luke, koji su, inače, bili aktivni u History Festu 2017. i 2018, da učestvuju u panelu u okviru History Festa održanom u tom gradu 2019. nerazumljivo, a optužbe koje su nakon toga uslijedile 
na račun History Festa od dijela historičara iz Banje Luke, a koje sada ponavlja Dragiša D. Vasić, izraz su njihove politizacije historije, a ne politizacije od strane organizatora History Festa.

\section{Literature}

- Bougarel, Xavier. Nadživjeti carstva: islam, nacionalni identitet i politička lojalnost u Bosni i Hercegovini, (prijevod sa francuskog). Sarajevo: Udruženje za modernu historiju, 2020.

- $\quad$ Donia, J. Robert. Iz Skupštine Republike Srpske. Izvodi iz izlaganja poslanika Skupštine Republike Srpske kao dokazni materijal na Međunarodnom krivičnom tribunalu u Hagu. Sarajevo: University Press, 2012.

- $\quad$ Donia, J. Robert. Sarajevo. A Biography. London: Hurst\&Company, 2006.

- Grunert, Heiner. „Raum, Zeit und deren Namen. Geschichte der Namen von Straßen und Plätzen in Sarajevo", rukopis. S. l., s. a.

- Haverić, Tarik. Kritika bosanskog uma. Ogled o jednom historijski fiksiranom mentalitetu. Sarajevo: ECLD, 2016.

- Historijski mitovi na Balkanu, zbornik radova, ur. Husnija Kamberović. Sarajevo: Institut za istoriju, 2003.

- $\quad$ Kamberović, Husnija. Historiografija u Bosni i Hercegovini u službi politike. Zagreb: Srednja Europa, 2012.

- Kamberović, Husnija. „Slučaj Mustafe Busuladžića - sa povijesne margine ka politikantskom centru“. Na margini povijesti, zbronik radova, 121-134. Sarajevo: Udruženje za mdernu historiju, 2018.

- Kamberović, Husnija. „Historičari kao nacionalni radnici i politizacija historiografske scene u Bosni i Hercegovini“. Ogledi o historiografiji i nacionalizmu u jugoistočnoj Evropi. zbornik radova, 149-170. Sarajevo: Udruženje za modernu historiju, 2019.

- $\quad$ Ković, Miloš, Draga Mastilović. Pravo na istoriju. Svedočenje u procesu Haškog tribunala protiv generala Ratka Mladića. Beograd: Catena mundi, 2018.

- Redžić, Enver. Stotinu godina muslimanske politike u tezama i kontroverzama istorijske nauke. Geneza ideje bosanske, bošnjačke nacije. Sarajevo: Akademija nauka i umjetnosti, Institut za istoriju, 2000.

- S Šušnica, Srđan. „Pop-mitološko označevanje 'naših' ulic. Študija primera Banje Luke, Bosna in Hercegovina“. Magistarsko delo, Ljubljana, 2015.

- Vasić, Dragiša D. „Istorija i nacionalni identitet u sarajevskoj magli: primjeri politizacije i mitologizacije bošnjačkog istorijskog narativa". Tokovi istorije 2/2020, 209-232. doi: 10.31212/tokovi.2020.2.vas.209-232

- Veličković, Nenad. Akademsko šarlatanstvo. Nauka o književnosti i univerzitet u tranziciji - etnografski pristup. Sarajevo - Beograd: Edicija Reč, 2019. 


\title{
Summary
}

Husnija Kamberović

\section{The Sarajevo Fog and the Teslić-Banja Luka "Brightness": Non-Scientific Attitudes in Dragiša D. Vasić's Text on the "Bosniak Historical Narrative"}

\begin{abstract}
This paper denies Dragiša D. Vasić's claims related to the condition of historiography in Sarajevo and shows the politicking nature and a lack of scientific quality of Vasić's article. On the example of renaming the streets of Sarajevo, "the Bosnian Valley of Pyramids", as well as the politics of history teaching in Sarajevo and the History Fest, the author shows that Vasić does not bring forth anything new; instead, he repeats the old and well-known theses that are not aimed at opening scientific discussions but rather at spreading hatred. The author claims that Vasić does not deal with the role of historiography, but presents the attitudes of political elites, which is why his approach to historiography is selective, nationalistic, containing political labelling, thus, according to all this, also completely non-scientific.

KEY WORDS: Historiography in Bosnia and Herzegovina, Politicking of History, Nationalism
\end{abstract}

In an article about the "Bosniak historical narrative", Dragiša D. Vasić claims that the contemporary Bosniak historiography has been politicised, providing four examples as arguments for his claim: changing the names of streets in Sarajevo, the relationship towards the "Bosnian Valley of Pyramids", certain examples of victimisation in the history textbooks used in the Sarajevo Canton, and the History Fest manifestation. Vasić's starting position is wrong, since the Bosniak historiography, as a methodological and a thematic concept, does not exist, while a significant number of scientists in Sarajevo, independent of their ethnic affiliation, did not support the use of historiography for political purposes, and they have criticised the relationship of the political elite towards the names of certain streets and schools in Sarajevo, especially the primary school in Dobroševići, named after Mustafa Busuladžić. Furthermore, a considerable number of members of the academic community in Bosnia and Herzegovina and in Sarajevo did not support the idea on the "Bosnian Valley of 
Pyramids", hence Vasić's claims of that being the "Bosniak historical narrative" are unfounded.

History textbooks are not of the best quality, not only in Sarajevo, but Vasić's approach to the analysis is selective, superficial, ethnocentric and non-scientific. His positions that Sarajevo was not under "siege" during the 1992-1995 war, rather "divided", and that a "mass atrocity" not a crime of genocide took place in Srebrenica, show that his approach to historiography is politicised. Although the textbooks used in the Sarajevo Canton contain elements of mythologization, the claims that Sarajevo was under siege from 1992 to 1995, and that a crime of genocide took place in Srebrenica are facts confirmed by the International Tribunal at the Hague.

The 2019 History Fest that Vasić writes about, describing it as a "political provocation", is an event bringing together historians from all over the world; it is not politically motivated and is held in different cities throughout Bosnia and Herzegovina for the purpose of facilitating scientific dialogue whilst preserving high scientific criteria. Participants do not represent any "national sides", hence, the Banja Luka historians' refusal to participate in the 2019 History Fest was unreasonable, especially since they had been active at the 2017 and 2018 History Fest. After that, accusations followed by some historians from Banja Luka against the History Fest and now they are repeated by Dragiša D. Vasić. Those accusations are the result of their politicisation of history, not politicisation by the organisers of the History Fest. 